\title{
EDITORIAL
}

\section{Stress ulcer prophylaxis: Is mortality a useful endpoint?}

\author{
Armin Finkenstedt ${ }^{1}$, Mette M. Berger ${ }^{2}$ and Michael Joannidis ${ }^{1 *}$ (D)
}

(0) 2020 Springer-Verlag GmbH Germany, part of Springer Nature

The risk of stress ulceration and related bleeding has long been a concern in critically ill patients. Since the first description of an association between major burns and the occurrence of gastric ulceration by J. Swan in 1823, several further risk factors for stress ulcerations have been identified. The two most common are mechanical ventilation for more than $48 \mathrm{~h}$ and coagulopathy [1], and others are listed in Table 1. Although gastric erosions have been found in up to $90 \%$ of patients on the third ICU day in endoscopic studies [2], overt gastrointestinal bleeding is much less frequent and occurs in $1.5 \%$ to $8 \%$ of patients. Nevertheless, overt bleeding from ulcerations is associated with an increased ICU mortality [3], and most guidelines recommend stress ulcer prophylaxis for ICU patients who are at risk for the development of ulceration and bleeding $[4,5]$.

After decades of randomized trials, stress ulcer prophylaxis remains debated. Although the efficacy of pharmacological prophylaxis has been confirmed for patients at high bleeding risk in numerous trials and meta-analyses enabling clear guidelines [5], the choice of the agent [H2 receptor antagonist (H2RA), proton pump inhibitors (PPI), or sucralfate] and its possible influence on mortality remains controversial. The major concerns are eventual association between stress ulcer prophylaxis and an increased risk of nosocomial pneumonia, Clostridium difficile infection, and mortality.

In this issue of Intensive Care Medicine, Wang and coworkers present the results from an update [6] of their previous systematic review and network meta-analysis

\footnotetext{
*Correspondence: michael.joannidis@i-med.ac.at

${ }^{1}$ Division of Intensive Care and Emergency Medicine, Department of Internal Medicine, Medical University Innsbruck, Anichstrasse 35, 6020 Innsbruck, Austria

Full author information is available at the end of the article
}

[7]. In addition to another very small trial, the authors included the PEPTIC trial, a multi-centre cluster randomized trial including over 26.000 patients [8] and thus increasing the number of analysed patients from 12660 to 39569 . This massive augmentation in numbers should have increased certainty, which is not the case. The present meta-analysis was motivated by an apparently increased mortality for PPIs over H2RAs in the PEPTIC trial [8], and compared potential benefits and harms of stress ulcer prophylaxis with PPIs, H2RAs, and sucralfate in critically ill patients.

The main finding of this latest meta-analysis of 74 individual trials [6] is that neither PPIs nor H2RAs compared to no prophylaxis are likely to have a significant influence on mortality, without any difference between PPIs and H2RAs. This meta-analysis is the latest of over 60 studies found on PubMed (access 3rd SEP20) since 1991 using the words "stress ulcer AND prophylaxis AND metaanalysis". The obtained findings are reaching, at best, a moderate certainty in effect estimates [8]. Thus, there is still no absolute certainty despite the advanced statistical tools used to re-run the data. Considering the fact that mortality apparently cannot provide sufficient guidance here, this should generate an in depth questioning about the current use of these drugs.

Basically, this updated meta-analysis confirms that stress ulcer prophylaxis by PPIs or H2RAs is only beneficial and recommended in patients with increased risk of gastrointestinal bleeding: neither PPIs nor H2RAs significantly reduce bleeding risk in patients with low $(<2 \%)$ and moderate risk (2-4\%) of gastrointestinal bleeding. In patients with high (4-8\%) and highest bleeding risk $(>8 \%)$, the reduction is important though, with an absolute reduction in bleedings reaching 20 to 49 per 1000 patients, respectively. The reduction was greater in PPIs than in HR2As or sucralfate.

\section{Springer}


Table 1 Proposal of bleedings risk categories and efficacy of stress ulcer prophylaxis according to Wang et al. in their two studies $[6,7]$. Of note: a universally accepted definition of bleeding risk categories is still lacking

\begin{tabular}{|c|c|c|c|c|c|c|}
\hline Risk group & Risk factors* & $\begin{array}{l}\text { Baseline risk } \\
\text { of clinically impor- } \\
\text { tant gastrointesti- } \\
\text { nal bleeding }\end{array}$ & $\begin{array}{l}\text { Baseline risk } \\
\text { of overt gastroin- } \\
\text { testinal bleeding** }\end{array}$ & $\begin{array}{l}\text { Effect of PPI } \\
\text { on bleeding risk }\end{array}$ & $\begin{array}{l}\text { Effect of H2RA } \\
\text { on bleeding risk }\end{array}$ & $\begin{array}{l}\text { Effect of sucralfate } \\
\text { on bleeding risk }\end{array}$ \\
\hline Low risk & $\begin{array}{l}\text { Critically ill patient } \\
\text { without any risk } \\
\text { factor; } \\
\text { Acute hepatic failure; } \\
\text { Use of steroids/ } \\
\text { immunosuppres- } \\
\text { sion; } \\
\text { Use of anticoagu- } \\
\text { lants; } \\
\text { Cancer; } \\
\text { Male gender }\end{array}$ & $1-2 \%$ & $2-6 \%$ & $\begin{array}{l}\text { Minimal reduction } \\
\text { but not enough to } \\
\text { justify use }\end{array}$ & $\begin{array}{l}\text { Minimal reduction } \\
\text { but not enough to } \\
\text { justify use }\end{array}$ & No significant effect \\
\hline Moderate risk & $\begin{array}{l}\text { Mechanical ventila- } \\
\text { tion with enteral } \\
\text { nutrition; } \\
\text { Shock; } \\
\text { Sepsis; } \\
\text { Acute kidney injury }\end{array}$ & $2-4 \%$ & $6-9 \%$ & $\begin{array}{l}\text { Minimal reduction } \\
\text { but not enough to } \\
\text { justify general use }\end{array}$ & $\begin{array}{l}\text { Minimal reduction } \\
\text { but not enough to } \\
\text { justify general use }\end{array}$ & No significant effect \\
\hline High risk & Coagulopathy & $4-8 \%$ & $9-16 \%$ & Significant reduction & $\begin{array}{l}\text { Significant reduction } \\
\text { but less than for } \\
\text { PPI }\end{array}$ & No significant effect \\
\hline Highest risk & $\begin{array}{l}\text { Mechanical ven- } \\
\text { tilation without } \\
\text { enteral nutrition; } \\
\text { Chronic liver disease }\end{array}$ & $8-10 \%$ & $16-22 \%$ & Significant reduction & $\begin{array}{l}\text { Significant reduction } \\
\text { but less than for } \\
\text { PPI }\end{array}$ & No significant effect \\
\hline
\end{tabular}

*Risk factors identified in the trials included in the two cited meta-analyses: mechanical ventilation, neurosurgery, brain injury, respiratory failure, sepsis, burns, hypotension, postoperative complications, acute renal failure, multiple trauma, acid-base disorder, coagulopathy, multiple surgical procedures, circulatory failure, coma, preoperative GCS $<9$, inappropriate secretion of antidiuretic hormone, major postoperative complications requiring reoperation, $\geq 60$ years old, pyogenic central nervous system infection, marked jaundice, shock, stroke or head trauma with GCS $<10$, corticotherapy, treatment with anticoagulants, hepatic failure, acute pancreatitis, major thoracic or abdominal surgery, renal replacement therapy, history of chronic liver disease, and major neurologic insult

**Overt gastrointestinal bleeding = bleeding without the consequences of clinically important gastrointestinal bleeding such as haemodynamic changes, transfusion, haemoglobin decrease, or need for surgery

The cost of a therapy that is not indicated in the majority of patients should be considered. Despite the absence of efficiency in low-risk patients, prophylaxis is still being used in between 70 and $90 \%$ of ICU patients [9]. In clinical practice, PPIs once started, are often continued after resolution of critical illness. A recent Indian audit revealed, that despite all the existing literature, there is a lack of awareness regarding initiation, choice of agent, adverse effects, as well as termination of ulcer prophylaxis [10]. Such inadequate prescription and maintenance was associated with a potential cost of $31^{\prime} 000-87^{\prime} 000 €$ per year as demonstrated by the Lausanne university ICU [11].

The next relevant finding of the latest meta-analysis is that neither PPIs, H2RAs, nor sucralfate seem to have an important impact on pneumonia. This observation contradicts the results from their original analysis, in which stress ulcer prophylaxis was associated with increased rates of pneumonia. In contrast to the previous analysis, only blinded studies were included for this estimate. Furthermore, no important differences in the risk of $\mathrm{C}$. difficile infection, length of ICU stay, and hospital stay or duration of mechanical ventilation was observed between the different prophylactic interventions.

Of note, the authors did not consider other aspects of stress ulcer prevention, such as enteral nutrition. Some data suggest a protective effect of the latter independent of the use of pharmacological stress ulcer prophylaxis [12]. Two meta-analyses have further questioned the effectiveness of pharmacological stress ulcer prophylaxis in patients receiving enteral nutrition and raised concern on an increased risk of nosocomial pneumonia in combined intervention [13, 14]. However, due to the lack of large prospective studies investigating this specific topic and significant heterogeneity between the included studies, no firm conclusions can be drawn. Therefore, we believe that stress ulcer prophylaxis is still indicated in patients with enteral nutrition and high bleeding risk, but indication for prophylaxis should regularly be reconsidered.

Although stress ulcer prophylaxis seems to be safe and efficient in patients at risk, not affecting mortality [5], 
uncertainty regarding other harmful effects remains. The issue of pharmacological interactions has not been addressed. It is obvious that H2RA, a potent cytochrome P450 inhibitor, has a longer list of potential drug interactions, not all of them being benign: this should motivate a more restricted use. Early enteral nutrition, which is possible in the majority of patients, might be as effective as these drugs in the low-risk patients, while reducing the risk of underfeeding [15]. Stress ulcer prophylaxis with PPI (or H2RA) should now be restricted to ICU patients at highest risk, and early enteral nutrition encouraged.

\author{
Author details \\ ${ }^{1}$ Division of Intensive Care and Emergency Medicine, Department of Internal \\ Medicine, Medical University Innsbruck, Anichstrasse 35, 6020 Innsbruck, \\ Austria. ${ }^{2}$ Adult Intensive Care Service, Lausanne University Hospital, Lausanne, \\ Switzerland.
}

\section{Author contributions}

All authors drafted, wrote, and approved the manuscript.

\section{Compliance with ethical standards}

\section{Conflicts of interest}

None of the other authors have any conflicts of interest to declare.

\section{Publisher's Note}

Springer Nature remains neutral with regard to jurisdictional claims in published maps and institutional affiliations.

Received: 11 September 2020 Accepted: 15 September 2020 Published online: 28 September 2020

\section{References}

1. Granholm A, Zeng L, Dionne JC, Perner A, Marker S, Krag M, MacLaren R, Ye Z, Moller MH, Alhazzani W, Group Guide (2019) Predictors of gastrointestinal bleeding in adult ICU patients: a systematic review and meta-analysis. Intensive Care Med 45:1347-1359

2. Eddleston JM, Pearson RC, Holland J, Tooth JA, Vohra A, Doran BH (1994) Prospective endoscopic study of stress erosions and ulcers in critically il adult patients treated with either sucralfate or placebo. Criti Care Med 22:1949-1954

3. Cook DJ, Griffith LE, Walter SD, Guyatt GH, Meade MO, Heyland DK, Kirby A, Tryba M, Canadian Critical Care Trials Group (2001) The attributable mortality and length of intensive care unit stay of clinically important gastrointestinal bleeding in critically ill patients. Crit Care 5:368-377

4. Rhodes A, Evans LE, Alhazzani W, Levy MM, Antonelli M, Ferrer R, Kumar A, Sevransky JE, Sprung CL, Nunnally ME, Rochwerg B, Rubenfeld GD, Angus DC, Annane D, Beale RJ, Bellinghan GJ, Bernard GR, Chiche JD, Coopersmith C, De Backer DP, French CJ, Fujishima S, Gerlach H, Hidalgo $J$, Hollenberg SM, Jones AE, Karnad DR, Kleinpell RM, Koh Y, Lisboa TC, Machado FR, Marini JJ, Marshall JC, Mazuski JE, McIntyre LA, McLean AS,
Mehta S, Moreno RP, Myburgh J, Navalesi P, Nishida O, Osborn TM, Perner A, Plunkett CM, Ranieri M, Schorr CA, Seckel MA, Seymour CW, Shieh L, Shukri KA, Simpson SQ, Singer M, Thompson BT, Townsend SR, Van der Poll T, Vincent JL, Wiersinga WJ, Zimmerman JL, Dellinger RP (2017) Surviving sepsis campaign: international guidelines for management of sepsis and septic shock: 2016. Intensive Care Med 43:304-377

5. Ye Z, Reintam BA, Lytvyn L, Wang Y, Guyatt GH, Mikita JS, Roberts J, Agoritsas T, Bertschy S, Boroli F, Camsooksai J, Du B, Heen AF, Lu J, Mella JM, Vandvik PO, Wise R, Zheng Y, Liu L, Siemieniuk RAC (2020) Gastrointestinal bleeding prophylaxis for critically ill patients: a clinical practice guideline. BMJ 368:16722

6. Wang Y, Ge L, Ye Z, Siemieniuk RA, Reintam BA, Wang X, Perner A, Moller MH, Alhazzani W, Cook D, Guyatt GH (2020) Efficacy and safety of gastrointestinal bleeding prophylaxis in critically ill patients: an updated systematic review and network meta-analysis of randomized trials. Intensive Care Med. https://doi.org/10.1007/s00134-00020-06209-w

7. Wang Y, Ye Z, Ge L, Siemieniuk RAC, Wang X, Wang Y, Hou L, Ma Z, Agoritsas T, Vandvik PO, Perner A, Moller MH, Guyatt GH, Liu L (2020) Efficacy and safety of gastrointestinal bleeding prophylaxis in critically ill patients: systematic review and network meta-analysis. BMJ 368:16744

8. Young PJ, Bagshaw SM, Forbes AB, Nichol AD, Wright SE, Bailey M, Bellomo R, Beasley R, Brickell K, Eastwood GM, Gattas DJ, van Haren F, Litton E, Mackle DM, McArthur CJ, McGuinness SP, Mouncey PR, Navarra L, Opgenorth D, Pilcher D, Saxena MK, Webb SA, Wiley D, Rowan KM, Investigators PEPTIC, Group for the ANZICS Clinical Trials, Network Alberta Health Services Critical Care Strategic Clinical, Group the Irish Critical Care Trials (2020) Effect of stress ulcer prophylaxis with proton pump inhibitors vs histamine-2 receptor blockers on in-hospital mortality among ICU patients receiving invasive mechanical ventilation: the PEPTIC randomized clinical trial. JAMA 323:616-626

9. Shears M, Alhazzani W, Marshall JC, Muscedere J, Hall R, English SW, Dodek PM, Lauzier F, Kanji S, Duffett M, Barletta J, Alshahrani M, Arabi Y, Deane A, Cook DJ (2016) Stress ulcer prophylaxis in critical illness: a Canadian survey. Can J Anaesth 63:718-724

10. Gupta D, Bhalotra AR, Singh R (2020) Audit on practices of stress ulcer prophylaxis in intensive care unit patients. Indian J Crit Care Med 24:160-167

11. Franchitti M, Piubellini J, Sadeghipour F, Eckert P, Voirol P, Schneider AG (2020) Adequacy of stress ulcer prophylaxis prescription in the intensive care unit: an observational study. Schweiz Med Wschr https://smw.ch/ article/doi/smw.2020.20322 Accessed 24 Aug 2020

12. Cook D, Heyland D, Griffith L, Cook R, Marshall J, Pagliarello J (1999) Risk factors for clinically important upper gastrointestinal bleeding in patients requiring mechanical ventilation. Canadian critical care trials group. Critical Care Med 27:2846-2847

13. Huang HB, Jiang W, Wang CY, Qin HY, Du B (2018) Stress ulcer prophylaxis in intensive care unit patients receiving enteral nutrition: a systematic review and meta-analysis. Crit Care 22:20

14. Marik PE, Vasu T, Hirani A, Pachinburavan M (2010) Stress ulcer prophylaxis in the new millennium: a systematic review and meta-analysis. Critical Care Med 38:2222-2228

15. Reintam Blaser A, Starkopf J, Alhazzani W, Berger MM, Casaer MP, Deane AM, Fruhwald S, Hiesmayr M, Ichai C, Jakob SM, Loudet Cl, Malbrain ML, Montejo Gonzalez JC, Paugam-Burtz C, Poeze M, Preiser JC, Singer P, van Zanten AR, De Waele J, Wendon J, Wernerman J, Whitehouse T, Wilmer A, Oudemans-van Straaten HM, Function Esicm Working Group on Gastrointestinal (2017) Early enteral nutrition in critically ill patients: ESICM clinical practice guidelines. Intensive Care Med 43:380-398 